\title{
Sjogren's syndrome: apoptosis by anti-SSA and anti-SSB antibodies
}

\section{Sindrome di Sjogren: apoptosi indotta da autoanticorpi anti-SSA e anti-SSB}

\author{
P. Scagliusi' ${ }^{1}$, M. D'Amore' ${ }^{1}$, S. D'Amore' ${ }^{2}$, A. Scagliusi ${ }^{3}$ \\ ${ }^{1}$ DIMIMP-Sezione di Reumatologia, ${ }^{2}$ DIMIMP-Sezione di Medicina Interna, \\ ${ }^{3}$ Dipartimento di Clinica Medica, Immunologia e Malattie Infettive, Sezione di Dermatologia; Università degli Studi di Bari
}

\begin{abstract}
Sirs,
The pathogenesis of the Sjogren's Syndrome (SjS) has not yet been completely defined. However, the cell-mediated immunity plays an important role and the apoptosis of the ductal and acinar epithelial cells is responsible of the glandular tissue damage, through the cytotoxic T-cells, particularly of the $\mathrm{CD} 4^{+}$subpopulation, by the release of proteases (such as perforin and granzyme B) and by the interaction of the Fas Ligand (FasL; CD95L) of the T-lymphocytes, with the Fas (Apo-1; CD95) of the epithelial cells. The apoptotic death of the epithelial cells is the autocrine Fas/FasL interaction also. The anti-SSA and anti-SSB antibodies are the immunological markers of the Sjogren's syndrome, but it is not yet understood if they have pathogenetic implications.

We have studied 6 patients with $\mathrm{SjS}$ and 6 voluntary healthy donors, to investigate, on human salivary gland cell line HTB-41, the possible activation of apoptotic pathways by the whole serum or by IgGs from the serum of patients with SjS or voluntary donors. Of the 6 serum of the $\mathrm{SjS}$ patients, 1 was with anti-SSA abs, 2 with anti-SSA and anti-SSB abs, 1 with anti-SSA abs and systemic sclerosis, 2 with anti-SSA and anti-SSB abs and rheumatoid arthritis. The sera were diluted $2 \%$; the respective $\mathrm{IgG}$ were isolated from each serum by ammonium sulphate precipitation and concentrated to final concentration of $20 \mathrm{mg} / \mathrm{ml}$; the whole serum or the $\mathrm{IgG}$ isolated were added to human salivary gland cell line HTB-41. The eventually induced apoptosis was
\end{abstract}

Indirizzo per la corrispondenza:

Prof. Pasquale Scagliusi

Via Conversano 500

C.P. Polignano a Mare (Bari)

E-mail: m1damore@libero.it measured by fluorescence microscopy after addition of YOPRO-1 (DNA-intercalating dye) to measuring the apoptotic cells. The DNA fragmentation was assessed by isolation of genomic DNA from HTB-41 cells, submitted to various treatments and to final separation by $1,8 \%(\mathrm{w} / \mathrm{v})$ agarose gel electrophoresis. A colorimetric assay and the immunoblotting analysis evaluated the intracellular activation of the effector caspase 3 .

The whole serum and the extracted $\operatorname{IgG}$ of the $6 \mathrm{pts}$ with $\mathrm{SjS}$ all induced the morphological signs of the apoptosis in 70\% of the HTB-41 cells. On the contrary, in the same conditions, no control serum induced signs of apoptosis. Furthermore, the DNA fragmentation and the caspase 3 activation were clearly evident only with the 6 serums of the 6 pts with $\mathrm{SjS}$ (alone or associated with other diseases), indipendently from the whole autoanticorpal pattern. The immunopathogenesis of Sjogren's syndrome start from a primary abnormality or from predisposing factors (1) or from infections agents (2). The apoptotic pathway plays a central role in $T$ cells tolerizia to tissue-specific self antigen, and may drive the autoimmune phenomenon. The antiestrogenic actions might be a potent factor in the formation of autoimmune lesions (3). The caspaseinhibitors prevent the development of autoimmune lesions in the salivary and lacrimal glands (4). In patients with $\mathrm{SjS}$ increase the expression of negative regulator molecules PD-1 (programmed cell death1), CTLA4 (cytotoxic T lymphocyte-associated antigen-4), the apoptotic signal molecules Fas and FasL (5) and of BAFF (B cell activating factor belonging to the TNF family) (6), that have central role in immunopatology $\mathrm{SjS}$. The our various results clearly show the apoptosis induced in vitro by the autoantibodies of serum of pts with $\mathrm{SjS}$ on human salivary gland cells. 


\section{REFERENCES}

1. Takei M, Shiraiwa H, Azuma T, Hayashi Y, Seki N, Sawada S. The possible etiopathogenic genes of Sjogren's syndrome. Autoimmun Rev 2005; 4: 479-84.

2. Hansen A, Lipsky PE, Dornet T. Immunopathogenesis of primary Sjogren's syndrome: implications for disease management and therapy. Curr Opin Rheumatol 2005; 17: 558-65.

3. Hayashi Y, Arakaki R, Ishimaru N. Apoptosis and estrogen deficiency in primary Sjogren syndrome. Curr Opin Rheumatol 2004; 16: 753.
4. Hayashi Y, Arakaki R, Ishimaru N. The role of caspase cascade on the development of primary Sjogren's syndrome. J Med Invest 2003; 50: 32-8.

5. Bolstad AI, Eiken HG, Rosenlund B, AlarconRiquelme ME, Jonsson R. Increased salivary gland tissue expression of Fas, Fas ligand, cytotoxic T lymphocyte-associated antigen 4 , and programmed cell death 1 in primary Sjogren's syndrome. Arthritis Rheum 2003; 48: 174-85.

6. Mackay F, Sierro F, Grey ST, Gordon TP. The BAFF/APRIL system: an important player in systemic rheumatic diseases. Curr Dir Autoimmun 2005; 8: 243-65. 